\title{
Abstract
}

\section{Anthropometrics: A forgotten gem in clinical assessment of obesity}

Authors: R Bhatti ${ }^{1}$, U M. Warshow ${ }^{2}$, M Joumaa $^{3}$, M ElSaban $^{4}$, F Nawaz ${ }^{4}$, A H Khamis ${ }^{5}$.

${ }^{1}$ Consultant Endocrinologist, Mediclinic Parkview Hospital, Dubai, UAE.

${ }^{2}$ Consultant Gastroenterologist, Mediclinic Parkview Hospital, Dubai, UAE.

${ }^{3}$ Dietician and bariatric co-ordinator, Mediclinic Parkview Hospital, Dubai, UAE.

${ }^{4}$ Medical student, Mohammad Bin Rashid University of Medicine and Health Sciences, Dubai, UAE.

${ }^{5}$ Professor of Biostatistics, Mohammad Bin Rashid University of Medicine and Health Sciences, Dubai, UAE. 
medRxiv preprint doi: https://doi.org/10.1101/2020.11.19.20234740; this version posted November 22, 2020. The copyright holder for this

\section{Background}

According to World Health Organization (WHO), United Arab Emirates (UAE) has one of the highest prevalence rates of obesity in the Middle East at 34\%. There is a paralleled rise in the incidence of related metabolic conditions, particularly type 2 diabetes, metabolic syndrome and non-alcoholic fatty liver disease (NAFLD). Body mass index (BMI) alone is an insufficient marker of abdominal adiposity and addition of waist circumference (WC) can help to assess the cardiometabolic risk.

\section{Aim}

To study the prevalence of obesity related diseases in a multidisciplinary weight management program and determine the relationship to obesity anthropometric indices.

\section{Methods}

This is a cross-sectional study conducted at Mediclinic Parkview Hospital in Dubai, UAE. 308 patients have been evaluated from January 2019 until September 2019 as part of a multidisciplinary weight management program. Key demographics, anthropometrics, and clinical data was analyzed using Statistical Package for Social Sciences software version 25 (SPSS Inc., Chicago, IL).

\section{Results}

Three hundred and eight patients taking part in the weight management program were studied. The population was constituted of 103 (33\%) males and $205(67 \%)$ females. The mean age was 41 years $( \pm 9.6)$ with a median BMI of $34.5( \pm 6.7)$ and $33.7( \pm 7.8)$ for males and females respectively. Mean waist circumference was $113.4 \mathrm{~cm}( \pm 23.3)$ and $103.5 \mathrm{~cm}( \pm 16.2)$, fat percent was $33.7 \%( \pm 11.6)$ and $45( \pm 6.8)$, fat mass was $41 \mathrm{~kg}( \pm 15.2)$ and $41.1( \pm 14.1)$, and visceral fat was $6.5 \mathrm{~kg}( \pm 3.2)$ and $3.1( \pm 1.8)$, for males and females respectively. The population was heterogeneous with 38 nationalities. BMI strongly correlated with waist circumference (male; female, $r=0.67 ; r=0.72$ ) and visceral fat (male; female, $r=0.89 ; r=0.78)$. Further, waist circumference was significantly associated with risk of diabetes, hypertension, and NAFLD. 
medRxiv preprint doi: https://doi.org/10.1101/2020.11.19.20234740; this version posted November 22, 2020. The copyright holder for this preprint (which was not certified by peer review) is the author/funder, who has granted medRxiv a license to display the preprint in perpetuity.

All rights reserved. No reuse allowed without permission.

\section{Conclusion}

The study has confirmed the high prevalence rates of obesity related diseases in a private hospital setting in a multinational cohort of obese patients. BMI and waist circumference are the most representative measures of obesity in our population and correlate with abdominal adiposity and obesity related diseases. Further studies will play a part in assessing the benefit of these measures during weight reduction interventions.

Key words: obesity, anthropometrics, waist circumference

Abbreviations: Body mass index (BMI), Waist circumference (WC), Hip circumference (HC), Waist hip ratio (WHR), Non-alcoholic fatty liver disease (NAFLD) 
medRxiv preprint doi: https://doi.org/10.1101/2020.11.19.20234740; this version posted November 22, 2020. The copyright holder for this

\section{Introduction}

According to WHO prevalence of overweight is reported as $70.9 \%$ in females and $70.5 \%$ in males while the prevalence of obesity is reported as $41.2 \%$ in females and $31.6 \%$ in males in UAE. ${ }^{1}$ The prevalence of overweight and obesity has increased worldwide as defined by BMI. The prevalence of overweight in Gulf Cooperation Council (GCC) (Bahrain, Kuwait, Qatar, Oman, Saudi Arabia and the UAE), in 2011, adults has been reported to be $48 \%$ amongst males and $35 \%$ amongst females, while the prevalence of obesity has been reported to be $24 \%$ amongst males and $40 \%$ amongst females. $^{2}$ In UAE in particular, a study conducted at the national level between 1999 and 2000 reported prevalence rates of $40 \%$ and 30\% for overweight and obesity, respectively, in Emirati and non-Emirati adults combined. ${ }^{3}$ In contrast, a more recent study reports a prevalence of $42 \%$ for overweight and $20 \%$ for obesity in 2012 among the same abovementioned population. ${ }^{4}$

There is a paralleled rise in the incidence of related metabolic conditions, particularly type 2 diabetes, metabolic syndrome and non-alcoholic fatty liver disease (NAFLD). ${ }^{5}$ However, BMI itself does not provide any information on body fat distribution, which may be more closely related to metabolic risk than BMI itself. Waist circumference is simple method in clinic practice to assess the abdominal adiposity. Waist circumference is strongly associated with cardiovascular mortality. ${ }^{6}$ Therefore; waist circumference should be used in conjunction with BMI to assess the metabolic risk according to World Health Organization report. ${ }^{7}$

The aim of our study was to look at anthropometric measures like WC, body fat percentage with BMI and their correlation with related metabolic conditions like diabetes, hypertension and NAFLD. 


\section{Methods}

\section{Study Design}

This is a cross-sectional observational study conducted at Mediclinic Parkview Hospital, Dubai, and UAE between January-September 2019. 308 patients enrolled in the hospital's multidisciplinary weight management program were included in this study.

\section{Definitions:}

BMI was defined as weight divided by height squared $\left(\mathrm{kg} / \mathrm{m}^{2}\right)$.

Waist circumference (WC), was defined as measurement midway between the lowest rib and the iliac crest using a flexible tape.

Hip circumference (HC) was measured at the level of the greater trochanters to the nearest millimetre using a flexible tape.

Waist-to-hip ratios (WHR) were obtained by dividing waist circumference by hip circumference.

\section{Variables}

According to World Health Organization (WHO) recommendations BMI is categorized as healthy weight (BMI 20-25), overweight (BMI 25-29.9) and obese (BMI $\geq 30){ }^{7}$

Men with a waist circumference of $<94,94-101.9$ and $\geq 102 \mathrm{~cm}$ were classified as normal weight, overweight and obese respectively, while women were classified in the same obesity categories on the basis of $\mathrm{WC}<80,80-87.9$ and $\geq 88 \mathrm{~cm}$. 
medRxiv preprint doi: https://doi.org/10.1101/2020.11.19.20234740; this version posted November 22, 2020. The copyright holder for this

Men with WHR $<0.90,0.90-0.99$ and $\geq 1.0$ were classified as normal weight, overweight or obese respectively, while women were classified in the same categories on the basis of WHR of $<0.80,0.80-0.84$ and $\geq 0.85$.

Normal fat percentage for women is defined between $21-35 \%$

Normal fat percentage man is defined between $8-24 \%$

Normal visceral fat ratio for women is below 1.2

Normal visceral fat ratio for men is below 2.1

\section{Data collection:}

Data was collected from electronic medical records Bayanaty® (InterSystems IRIS, US) and Seca medical body composition analyzer 514(Seca®, Germany). Data collection was done in four categories: Demographic data, anthropometric measures, laboratory measurements, and clinical disease and risk factors status.

Demographic data included age, gender and nationality. Anthropometric measures included height, weight, BMI, fat mass, body fat percentage, and visceral fat mass, WC, HC and WHR. Laboratory measurements included glycated haemoglobin $(\mathrm{HbA} 1 \mathrm{c})$, renal function such as creatinine and estimated glomerular filtration rate (eGFR), liver function tests including AST and ALT, lipid profile including cholesterol, triglyceride, LDL, and HDL. Clinical variables included presence of diabetes, hypertension, polycystic ovarian syndrome, dyslipidemia and non-alcoholic fatty liver disease (NAFLD).

\section{The definition of metabolic risk factors}

Four Metabolic syndrome components were included in the analysis: elevated BP (130 $\mathrm{mmHg}$ and/or diastolic blood pressure $85 \mathrm{mmHg}$ or drug treatment for hypertension), HbA1c (6.5\% or 
medRxiv preprint doi: https://doi.org/10.1101/2020.11.19.20234740; this version posted November 22, 2020. The copyright holder for this

diabetes treatment), high TG concentration $(150 \mathrm{mg} / \mathrm{dl}$ or $1.7 \mathrm{mmol} / \mathrm{L}$ or drug treatment for elevated triglycerides), and low HDL cholesterol.

$(<40 \mathrm{mg} / \mathrm{dl}$ or $1.0 \mathrm{mmol} / \mathrm{L}$ in men and, $50 \mathrm{mg} / \mathrm{dl}$ or $<1.3 \mathrm{mmol} / \mathrm{L}$ in women or drug treatment).

\section{Statistical methods}

Data was entered in computer using IBM-SPSS for windows version 25.0 (SPSS Inc., Chicago, IL). Frequency tables and measure of percentage and measure of tendency and dispersion were performed as descriptive. Categorical variables were cross-tabulated to examine the independency between variables, for such variables the chi-square test or Fisher's exact test as appropriate were used. Kolmogorov-Smirnov was used to test the normality of continuous variables. The MannWhitney test was used to compare the means between two groups if the normality was not confirmed while t-test was used for normal data per groups. A p-value of less than 0.05 was considered significant in all statistical analysis.

\section{Ethical Statement}

Ethical approvals were taken from local Mediclinic Institutional Research Board; and Dubai Scientific Research Ethics Committee, Dubai Health Authority, Dubai, UAE. 
medRxiv preprint doi: https://doi.org/10.1101/2020.11.19.20234740; this version posted November 22, 2020. The copyright holder for this preprint (which was not certified by peer review) is the author/funder, who has granted medRxiv a license to display the preprint in perpetuity.

\section{Results}

A total of 308 patients were included in the study. 67\% $(n=205)$ were females. Mean age was 41.11 years. These patients represented 38 different nationalities. Basic demographics are shown in table 1.

$30 \%(\mathrm{n}=91)$ were overweight and $70 \%(\mathrm{n}=217)$ were obese according to WHO criteria using $\mathrm{BMI}$ and gender specific WC.

Table 1: Basic demographics

\begin{tabular}{|l|l|}
\hline Total no of patients & 308 \\
\hline Gender & No $(\%)$ \\
\hline Male & $103(33.4)$ \\
\hline Female & $205(66.6)$ \\
\hline Age & \\
\hline Mean (SD) & $41.11(9.6)$ \\
\hline Nationality & \\
\hline Asia & $58(19.1)$ \\
\hline Arab & $94(30.9)$ \\
\hline Europe & $56(18.4)$ \\
\hline America & $18(5.9)$ \\
\hline Africa & $72(23.7)$ \\
\hline New Zealand and Australia & $6(2)$ \\
\hline
\end{tabular}


medRxiv preprint doi: https://doi.org/10.1101/2020.11.19.20234740; this version posted November 22, 2020. The copyright holder for this preprint (which was not certified by peer review) is the author/funder, who has granted medRxiv a license to display the preprint in perpetuity.

All rights reserved. No reuse allowed without permission.

Table 2 represents gender specific general characteristics of patients. Males had higher weight, height, WC, BMI and visceral fat while females had higher \% calculated fat which was statistically significant $(\mathrm{p}<0.05)$

Table 2: General characteristics of the sample

\begin{tabular}{|l|l|l|c|}
\hline & Male $(\mathrm{n}=103)$ & Female $(\mathrm{n}=205)$ & $\mathrm{p}$-value \\
\hline Weight & $110.2(23.8)$ & $88.9(20.1)$ & $<0.001$ \\
\hline \% fat calculated & $33.7(11.6)$ & $41.8(13.7)$ & $<0.001$ \\
\hline$\%$ fat & $75.4(372.3)$ & $45.0(6.8)$ & 0.43 \\
\hline WC & $113.4(23.3)$ & $103.5(16.2)$ & $<0.01$ \\
\hline HC & $127.1(12.2)$ & $124.2(14.7)$ & 0.388 \\
\hline W:H ratio & $0.93(0.2)$ & $0.87(0.1)$ & 0.078 \\
\hline Height & $170.9(35.5)$ & $155.4(33.7)$ & $<0.001$ \\
\hline BMI & $34.5(6.7)$ & $33.7(7.8)$ & 0.006 \\
\hline Fat mass & $41.0(15.2)$ & $41.1(14.1)$ & 0.86 \\
\hline Visceral fat & $6.5(3.2)$ & $3.1(1.8)$ & $<0.001$ \\
\hline
\end{tabular}


medRxiv preprint doi: https://doi.org/10.1101/2020.11.19.20234740; this version posted November 22, 2020. The copyright holder for this preprint (which was not certified by peer review) is the author/funder, who has granted medRxiv a license to display the preprint in perpetuity.

Laboratory data was also compared between overweight and obese cases among different gender TG was found significantly higher among obese compared with overweight in males. ALT and HDL were found statistically significant between overweight and obese among females HDL was found less among obese while ALT was found higher among obese.

Table 3: Comparison of lab measurements between overweight cases and obese cases by gender

\begin{tabular}{|l|l|l|r|l|l|r|}
\hline & \multicolumn{5}{|c|}{ Male } & \multicolumn{3}{c|}{ Female } \\
\hline & overweight & Obese & p-value & overweight & Obese & p-value \\
\hline HbA1C & $5.62(0.55)$ & $6.26(1.62)$ & 0.326 & $5.75(0.73)$ & $5.57(0.95)$ & 0.15 \\
\hline Creatinine & $94.82(20.82)$ & $(20.33)$ & 0.231 & $62.35(7.96)$ & $65.06(7.98)$ & 0.203 \\
\hline \multirow{2}{*}{ eGFR } & & 93.68 & & 105.05 & & \\
\hline & & & & & & \\
AST & $35.37(19.68)$ & $(20.64)$ & 0.427 & $(11.7)$ & $98.83(17.5)$ & 0.12 \\
\hline \multirow{2}{*}{ ALT } & $31.25(10.9)$ & $(38.69)$ & 0.451 & $(13.23)$ & $(29.78)$ & 0.049 \\
\hline Cholesterol & $5.96(0.29)$ & $9.46(28.9)$ & 0.77 & $5.2(1.8)$ & $10.4(33.13)$ & 0.534 \\
\hline TG & $1.24(0.27)$ & $2.36(1.33)$ & 0.01 & $1.14(0.45)$ & $1.57(0.79)$ & 0.067 \\
\hline LDL & $3.44(1.71)$ & $6.41(20.67)$ & 0.73 & $3.59(1.13)$ & $3.58(0.86)$ & 0.978 \\
\hline HDL & $2.35(1.91)$ & $1.93(6.18)$ & 0.735 & $1.48(0.36)$ & $1.21(0.3)$ & 0.004 \\
\hline
\end{tabular}

The proportion of diabetes was found significantly higher among obese male, while hypertension was found higher among obese female. Dyslipidaemia was higher among obese female. Levels of ALT as a surrogate for NAFLD were significantly higher in female obese patients (shown in Table 4) 
medRxiv preprint doi: https://doi.org/10.1101/2020.11.19.20234740; this version posted November 22, 2020. The copyright holder for this preprint (which was not certified by peer review) is the author/funder, who has granted medRxiv a license to display the preprint in perpetuity.

All rights reserved. No reuse allowed without permission.

Table 4: Comparison complications between overweight cases and obese cases by gender

\begin{tabular}{|c|c|c|c|c|}
\hline & \multicolumn{2}{|l|}{ Male } & \multicolumn{2}{|l|}{ Female } \\
\hline Complications & overweight & Obese & overweight & Obese \\
\hline \multicolumn{5}{|l|}{ Diabetes } \\
\hline No & $11(91.7)$ & $29(50.9)$ & $37(78.7)$ & $63(72.4)$ \\
\hline Yes & $1(8.3)$ & $28(49.1)$ & $10(21.3)$ & $24(27.6)$ \\
\hline p-value & \multicolumn{2}{|l|}{0.008} & \multicolumn{2}{|l|}{0.279} \\
\hline \multicolumn{5}{|l|}{ HTN } \\
\hline No & $7(58.3)$ & $28(47.5)$ & $40(90.9)$ & $60(70.6)$ \\
\hline Yes & $5(41.7)$ & $31(52.5)$ & $4(9.1)$ & $25(29.4)$ \\
\hline P-value & \multicolumn{2}{|l|}{0.356} & \multicolumn{2}{|l|}{0.006} \\
\hline \multicolumn{5}{|l|}{ PCOS } \\
\hline No & $11(100)$ & $42(100)$ & $34(79.1)$ & $62(73.8)$ \\
\hline yes & 0 & 0 & $8(18.6)$ & $22(26.2)$ \\
\hline P-value & \multicolumn{2}{|l|}{ NA } & \multicolumn{2}{|l|}{0.235} \\
\hline \multicolumn{5}{|l|}{ Dyslipidaemia } \\
\hline No & $5(41.67)$ & $10(17.54)$ & $22(59.46)$ & $39(52.70)$ \\
\hline Yes & $7(58.33)$ & $47(82.26)$ & $15(40.54)$ & $35(47.30)$ \\
\hline P-value & \multicolumn{2}{|l|}{0.109} & \multicolumn{2}{|l|}{0.016} \\
\hline \multicolumn{5}{|l|}{ NAFLD } \\
\hline No & $3(60)$ & $19(45.52)$ & $20(95.23)$ & $39(72.22)$ \\
\hline Yes & $2(40)$ & $23(54.48)$ & $1(4.77)$ & $15(27.78)$ \\
\hline P-value & 0.248 & & 0.045 & \\
\hline
\end{tabular}

Correlation between BMI, WC, HC, visceral fat, \% of fat calculated and WHR was investigated using BMI and gender specific cutoffs for WC and other variables. The results are represented in figure 1 . 
medRxiv preprint doi: https://doi.org/10.1101/2020.11.19.20234740; this version posted November 22, 2020. The copyright holder for this preprint (which was not certified by peer review) is the author/funder, who has granted medRxiv a license to display the preprint in perpetuity.

All rights reserved. No reuse allowed without permission.

BMI, WC and visceral fat showed strong significant correlation with each other while WHR showed weak correlation with other anthropometric measures.

Figure 1: Matrix of correlation of the measurements of the indicators of anthropometrics of obesity

\begin{tabular}{|c|c|c|c|c|c|c|}
\hline \multicolumn{2}{|l|}{ Female } & \multirow[b]{2}{*}{ WC } & \multirow[b]{2}{*}{$\begin{array}{l}\% \text { fat } \\
\text { calculated }\end{array}$} & \multirow[b]{2}{*}{ Visceral fat } & \multicolumn{2}{|l|}{ Male } \\
\hline & BMI & & & & $\mathrm{HC}$ & WHR \\
\hline BMI & --- & $.686 * *$ & $.338 * *$ & $.898 * *$ & $.885^{* *}$ & 0.064 \\
\hline $\mathrm{WC}$ & $.651 * *$ & --- & $.431 * *$ & $.677 * *$ & $.853 * *$ & 0.424 \\
\hline$\%$ fat calculated & $.182 * *$ & $.295 * *$ & --- & $.632 * *$ & $.480 *$ & $.581 *$ \\
\hline Visceral fat & $.782 * *$ & $.727 * *$ & $.484 * *$ & --- & $.751 * *$ & $.516^{*}$ \\
\hline $\mathrm{HC}$ & $.532 * *$ & $.651 * *$ & $.521 * *$ & $.721 * *$ & --- & 0.135 \\
\hline WHR & $.383 * *$ & $.540 * *$ & -0.127 & $.396 * *$ & $-0232^{*}$ & --- \\
\hline
\end{tabular}


medRxiv preprint doi: https://doi.org/10.1101/2020.11.19.20234740; this version posted November 22, 2020. The copyright holder for this

\section{Discussion}

In this study from a multidisciplinary weight management program in Dubai $30 \%$ were overweight and $70 \%$ were obese. According to WHO prevalence of obesity is reported as $34 \%$ in UAE in 2016 and our data is reflective of this high background prevalence.

Majority were female (67\%) with participants from 38 different Nationalities as -Dubai is a multinational country with more than 200 nationalities.

BMI, WC and visceral fat show a strong significant correlation with each other. The correlation of WC to visceral fat establishes its benefit when combined with BMI and their correlation with each other suggests that measures of obesity based on these parameters will provide comparable information. Kamadieu et al demonstrated similar results in a Cameroon burden of diabetes baseline survey ${ }^{8}$ It is notable that increase in abdominal visceral adiposity is reflected by waist circumference and is related to increased cardio metabolic risk. ${ }^{6} \mathrm{WHR}$ has a weak correlation with other anthropometric measures in our cohort.

Our laboratory data showed that triglycerides were elevated in obese males. In obese women, ALT levels were significantly higher, as was prevalence of NAFLD. There was a statistically significant low HDL in obese females. Thus, our cohort reflected a gender difference in prevalence of obesity related conditions such hypertension, dyslipidemia and NAFLD.

The findings of our study has important implications on assessment of obesity in clinical practice as it reinforces the use of anthropometrics as indicators of obesity. The International atherosclerosis society (IAS) and international chair on cardiometabolic risk (ICCR) working group also published a consensus statement on visceral obesity in March 2020. It also recommended use of WC as a critically important target for reducing adverse health risks for both men and women. ${ }^{9}$ Recent Canadian guidelines for obesity in adults also recommend measurement of waist circumference in addition to BMI to identify individuals with increased visceral adiposity and adiposity related health risks. ${ }^{10}$ 
medRxiv preprint doi: https://doi.org/10.1101/2020.11.19.20234740; this version posted November 22, 2020. The copyright holder for this preprint (which was not certified by peer review) is the author/funder, who has granted medRxiv a license to display the preprint in perpetuity.

All rights reserved. No reuse allowed without permission.

The limitations of our study include small sample size. More studies are needed to see the implications of anthropometrics on clinical outcomes of different weight management interventions.

\section{Conclusion}

According to findings of our study, there is strong correlation between BMI, visceral fat and waist circumference. It highlights the importance of using anthropometrics such as waist circumference as measure of obesity in addition to BMI and it is easy and inexpensive clinical tool.

\section{Funding source}

None.

\section{Conflicts of Interest}

None 


\section{References}

1-World Health Organization. Prevalence of obesity (Article online). Available:https://www.who.int/diabetes/country-profiles/are_en.pdf (Accessed 13th November 2020)

2-Alhyas L, McKay A, Balasanthiran A, Majeed A. Prevalences of overweight, obesity, hyperglycaemia, hypertension and dyslipidaemia in the Gulf: systematic review. JRSM Short Rep. 2011;2(7):55. doi: 10.1258/shorts.2011.011019.

3-F. Al-Haddad, Y. Al-Nuaimi, B. B. Little, and M. Thabit, "Prevalence of obesity among school children in the United Arab Emirates," American Journal of Human Biology, vol. 12, no. 4, pp. 498-502, 2000.

4-A. Yusufali, N. Bazargani, K. Muhammed et al., "Opportunistic screening for CVD risk factors: the Dubai shopping for cardiovascular risk study (DISCOVERY)," Global Heart, vol. 10, no. 4, pp. 265-272, 2015.

5-World Health Organization. Waist circumference and wait hip ratio. Report of a WHO consultation. Geneva: World Health Organization.2008.

https://apps.who.int/iris/bitstream/handle/10665/44583/9789241501491_eng.pdf

6-Song, $\mathrm{X}$ et al. Comparison of various surrogate obesity indicators as predictors of cardiovascular mortality in European populations. Eur J Clin. Nutr. 67, 1298-1302 (2013). 7-(WHO) WHO: Obesity: Preventing and Managing the Global Epidemic. Report of WHO Consultation on Obesity, 3-5 June 1997. Geneva: WHO, 1998. Edited by: WHO. Geneva; 2006. 8-Kamadjeu RM, Edwards R, Atanga JS, Kiawi EC, Unwin N, Mbanya JC: Anthropometry measures and prevalence of obesity in the urgan adult population of Cameroon: an update from the Cameroon Burden of Diabetes Baseline Survey. BMC Public Health. 2006, 13 (6): 22810.1186/1471-2458-6-228.

9-Ross, R. et al. Waist circumference as a vital sign in clinical practice: a consensus statement from the IAS and ICCR Working Group on Visceral Obesity. Nat. Rev. Endocrinol. 16, 177-189 (2020).

10- S Wharton, D Lau, M Vallis, et al. Obesity in adults: a clinical practice guideline. CMAJ 2020;192:E875-E891. 